\title{
3.10 The 2014 Sochi Winter Olympics: who stands to gain?
}

\author{
Oleg Golubchikov ${ }^{1}$
}

\section{Introduction}

The Sochi Winter Olympics and Winter Paralympics, which took place in February/March 2014, made the news worldwide as the most expensive events in history. While the initial bid's cost estimate for the Games was in the range of US\$11 billion, the final bill skyrocketed to US\$50 billion. Much of this cost has been borne by the federal budget, state-owned corporations and stateunderwritten loans. $^{2}$

It is easy to assume, as many did, ${ }^{3}$ that the high cost was merely a testimony to mismanagement and corruption. This is to ignore the results of earnest probing into the causes and implications of expensive sporting mega-events, however, including how symptomatic they are of the wider tendencies of transnational sport to intersect with national economies and politics. Global sporting events, including the Olympic Games, are some of the most conspicuous mega-projects. What is the function of mega-projects, though? As Bent Flyvbjerg argues, mega-projects 'are designed to ambitiously change the structure of society, as opposed to smaller and more conventional projects that...fit into pre-existing structures and do not attempt to modify these' ${ }^{4}$ It can be further contended that, as nation states 'hollow out' (that is, experience a weakened capacity to project their economic powers over their own territories in the face of globalisation, welfare state retrenchment and the increasing self-reliance of subnational regions), mega-projects remain one of the few important means still available to national governments to pursue radical structural strategies with respect to national spatial development. 
Similarly, the Sochi Olympic project reflects a strategy of the Putin Government to modernise Russian geography. Indeed, as documented below in this article, almost 80 per cent of the Sochi cost was unrelated to sport. This is well reflected in the official rhetoric: the Winter Olympic Games were seen as as a lever for an overhaul of Sochi and making it a new 'growth pole' in the country. ${ }^{5}$ This rationale goes beyond the direct calculus of the Games themselves, or even the expectation of a direct financial payback. This is not without controversies, however, including over issues such as the transparency of decision-making and the juxtaposition of the costs versus wider benefits of such geographically concentrated modernisation projects.

This article further outlines the context behind the Sochi project and its costs, and provides an assessment of the Olympic legacy in the aftermath of these Games.

\section{Counting the cost of Sochi}

The political dimension of the Sochi Games is well recognised; indeed, most commentators have argued that, much like, for example, the Beijing Olympics before them, the Sochi Games were an attempt to display Russia's re-emerging power to the rest of the world. ${ }^{6}$ What is missing in this discourse, however, is the fact that the Sochi Games sought not only (and probably not so much) to put Russia on the map of world powers but to put Sochi on Russia's (and world) map. ${ }^{7}$ Here, the Sochi Games should be seen in the context of the Putin government's attempts to restructure Russia's regional geography, based on the premise of promoting a few select locations as 'strategic' (economically and geopolitically) and making them the key nodes of Russia's spatial modernisation. ${ }^{8}$ Sochi has been 'appointed' as one such location; the city has long been favoured by President Putin as a sea resort, and it has an important geostrategic location at the Black Sea and the Caucasus. The Winter Olympics worked as the catalyst for the city's elevation within Russian geography. 
This politics of growth poles is by no means idiosyncratic to Russia, nor was it born there ${ }^{9}$ but Russia, like other quasi-authoritarian emerging economies, does particularly rely on government spending and administrative leverages. The main sponsors of the Olympics have been large corporations, most of which are state-controlled (such as Gazprom and Rosneft), while key private investors took state-underwritten credits from state-owned banks (such as VEB and Sberbank). ${ }^{10}$

Sochi has become the first Olympic city for which the entire main sports infrastructure was constructed from scratch and the existing transport infrastructure and hospitality sector were thoroughly remade. Overall, more than 800 construction objects were built in Sochi. Some of these were, of course, sporting facilities, but most of the cost was associated with a generic upgrade of the urban and regional infrastructure, including power stations and supply, new water and sewerage systems, telecommunications, a massive transport network, and so forth. ${ }^{11}$

The resultant Sochi expenses are commonly reported as some US\$50 billion - a considerable portion of Russia's GDP (Graph 3.2). This roughly corresponds to the official figures of Olympstroy, the state corporation managing and overseeing the preparations for Sochi. ${ }^{12}$ In its 2013 (final) budget statement from June 2014, it reported total allocated funds of RUB 1,524.4 billion (US $\$ 49.4$ billion) and funds actually spent by the end of 2013 as RUB $1,415.2$ billion (US $\$ 45.9$ billion). ${ }^{13}$

How much of this was directly related to sport? According to the Accounts Chamber of the Russian Federation, ${ }^{14}$ the direct cost of the Games and the sporting facilities was RUB 324.9 billion(US $\$ 10.5$ billion), including RUB 103.3 billion (US $\$ 3.3$ billion) directly funded by the federal budget. This suggests that around 21 per cent of the total Sochi spending can be attributed to the sporting side. ${ }^{15}$ 
This peculiar cost structure was already part of Russia's original bid; the total budget was then envisaged at RUB 313.9 billion (or some US\$11.3 billion at the exchange rate prevailing then), however. ${ }^{16}$ These moneys were allocated for the Federal Target Programme (FTP) for the Development of Sochi as a Mountain Climate Resort, which framed the Olympic bid. ${ }^{17}$ What is interesting is that the FTP was also allocated RUB 122.9 billion (US $\$ 4.4$ billion) in case Russia's bid for the Winter Olympics was declined in 2007. Although that was much less than in the Olympic scenario, it still signifies the strategy of making Sochi a development hotspot.

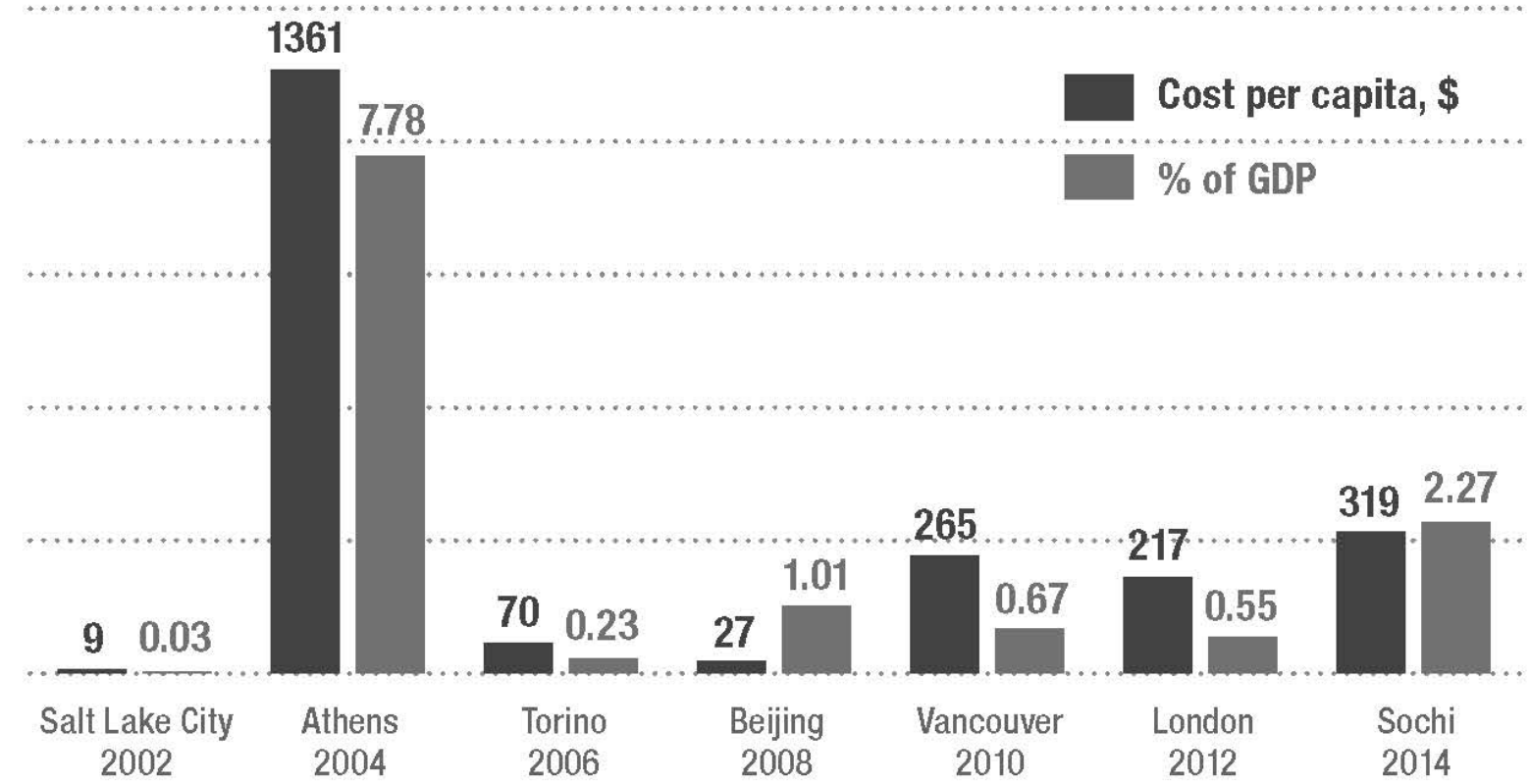

Figure 3.7 Costs of the Olympic Games per capita and as a percentage of GDP 2002-2014

Source: Anti-Corruption Foundation, Sochi 2014: Encyclopedia of Spending (Moscow: Anti-Corruption Foundation, 2014), http://sochi.fbk.info/en.

\section{Public participation and transparency investigations}

The high bill for the Winter Olympics, and particularly its inflation since 2007, have attracted much criticism within and outside Russia. ${ }^{18}$ State finances were greatly involved, and the main corporate investors and banks were also heavily exposed to the overspending. ${ }^{19}$ The overspends are attributed to a number of factors - notably a lack of sufficient preparatory investigations at the bidding stage, and underestimations of the challenging engineering conditions in the swampy Imereti Valley as well as other areas where the projects were built; other factors included the poor quality of the 
initial design specifications, additional emerging requirements of the International Olympic Committee (IOC) and inflation. ${ }^{20}$ Embezzlement and kickbacks almost certainly played a role too as proved by a number of official investigations. ${ }^{21}$ The full extent of corruption is open to speculation, but such speculation often ignores the other factors leading to overspending. ${ }^{22}$ Indeed, even private investors experienced considerable overspends; for example, Interros, the main investor and owner of the Rosa Khutor Alpine resort, saw a sixfold increase in its costs, from the planned US\$350 million to US\$2.07 billion. ${ }^{23}$

Nevertheless, there has been a perceived lack of follow-up investigations to existing corruption allegations. Despite the official rhetoric of transparency and participation, the Olympics monetary flows and, in particular, contract allocation procedures were not exposed to public scrutiny in a systematic manner, while public participation commonly remained nominal. ${ }^{24}$

The most prominent and critical public investigation reviews have been those prepared by representatives of Russia's opposition, including with the participation of the opposition leaders Alexei Navalny ${ }^{25}$ and the late Boris Nemtsov. ${ }^{26}$ A report produced by Nemtsov in collaboration with Leonid Martynyuk, for example, accused the Putin government of a deliberate plot to make the most expensive games in a challenging location as an opportunity for malfeasance and the distribution of state resources to the benefit of "Putin's cronies". A report by Navalny's AntiCorruption Foundation quoted personal ties between contractors and government officials as the most frequent point of concern over the Olympic projects. It needs to be borne in mind, however, that this reflects the objective realities of corporate capacity to undertake large-scale projects, given the oligarchic structure of Russia's economy. ${ }^{27}$

At the same time, there has surely been a lack of information about government-led investigations, even though it is known that a number of criminal investigations were launched following 
inspections by the Accounts Chamber of the Russian Federation, the country's principal financial watchdog. ${ }^{28}$ Most of the Accounts Chamber's discoveries seem to have not led anywhere, however. For example, it was reported that in its 2012 annual report the Accounts Chamber accused Olympstroy's executives of creating the conditions for an unjustified increase in the estimated costs of the sports facilities, resulting in a cost increase of RUB 15.5 billion (around US\$500 million). ${ }^{29}$ Ever since the resignation of its long-serving head, Sergei Stepashin, in September 2013, however, little has emerged about further investigations. Moreover, the Account Chamber's full reports have not been made available to the public, on the pretext that to do so would disclose commercially sensitive information. ${ }^{30}$

Generally, the extant expectations of widespread corruption investigations once the Games were over have failed to materialise. ${ }^{31}$ This may be attributable to the post-Olympic environment of public satisfaction with the successful execution of the Games in general and the outstanding performance of the Russian team in particular, as well as the ensuing geopolitical tensions over Ukraine, which overshadowed Sochi.

Usually, an important role in directing public attention is played by the mass media and investigative journalism. During the preparations for the Games, however, their interventions with respect to corruption were limited. The Western media gave prominence to a series of stories that exploited the stereotypes of the Western audiences but provided little evidence of investigative journalism. Some Russia-based journalists and organisations attempted more in-depth investigations, highlighting structural problems such as environmental concerns in the Sochi National Park, migrant labour exploitation and resettlement problems. ${ }^{32}$ Even so, there were no sustained and unbiased follow-ups to the cases of alleged corruption. 


\section{Sochi in the aftermath of the Winter Olympic Games}

The high Sochi spending aside, what is the economic impact of the Games on the host city? The Olympic legacy in the immediate aftermath of the Games appears to be rather mixed.

To start with, the city has been thoroughly retrofitted, while the continuous media and government focus on the Sochi Winter Olympics and other events in Sochi has made the city an easily recognisable 'brand'. Without doubt, the holding of the Winter Olympics in Sochi has changed not only the hitherto deteriorating resort city but also the mental geography of Russia in the eyes of the Russian population itself. This is reflected in the rise of tourism to Sochi. After the years when Sochi was 'Russia's largest construction site', with all the associated hassles and troubles, since 2014 Sochi has begun to enjoy an increase in visitor numbers. The Winter Olympics appear to have made the largest contribution to this, but the trend has been maintained through the rest of 2014 and into 2015. The city's mayor is reported to expect 5.5 million tourists coming to Sochi in 2015, a rise from the 5.18 million arrivals in $2014,{ }^{33}$ and sharply up on the 3.7 million in 2006 before the Olympic project got under way. ${ }^{34}$

The rise in tourism is a welcome trend to city residents, who endured the years of construction disruption, often combined with a loss of tourism-related income and, sometimes, employment. In addition, hundreds of people were removed from their former sites when they were subject to compulsory purchase, and were compensated only for legally registered properties, not for any informal extensions, including those used as guest rooms. ${ }^{35}$ Therefore, one year on from the Games, Sochi residents remained divided as to whether the Winter Olympics had benefited them or not. ${ }^{36}$

Tourists are attracted to Sochi for various reasons: the new or modernised skiing resorts; the Olympic parks; the sea resort facilities; and the post-Olympic sporting and business events and conferences that the government encourages to go to the city, such as the Grand Prix in 2014, some 
matches of the 2018 men's football World Cup and many others. ${ }^{37}$ Tourism helps in returning capital invested in the hospitality business and bringing in jobs and tax revenues. ${ }^{38}$ Nonetheless, tourism in Sochi cannot escape the wider geopolitical context, and Russia's economic troubles because of the fall in oil prices since $2014 .{ }^{39}$ On the one hand, as the real incomes of the Russian population have dropped, many Russians can no longer spend money on tourism - disadvantaging Sochi. On the other hand, as the Russian rouble has lost its international value, many have switched their holiday plans to internal tourism, thus benefiting the city. As a further complication, the annexation of Crimea - another prime holiday destination for Russians - will probably represent a competitive challenge for Sochi's tourism.

Uncertainties remain over the economic future of some key sporting facilities in Sochi. ${ }^{40} \mathrm{The}$ Games themselves were held in two clusters, largely separated and distant from the main urban areas and the city centre. The coastal cluster contains the Olympic Park, where the main sports facilities and the Olympic Village are located. The mountain cluster contains the skiing facilities and alpine resort infrastructure. Although the cluster approach produced a concentration of all activities in these two areas, thus preventing traffic congestion, providing easier access and facilitating security measures, it also raised the issue of remoteness. For example, when no sporting or other events are taking places in the Olympic Park, the facilities appear to be rather empty. On this basis, many commentators have been quick to prophesy that the key stadiums are doomed to collect dust and fall into disrepair. Although a direct payback on the investment in these facilities is indeed questionable (also exposing the lack of planning for a post-Olympic legacy), ${ }^{41}$ the future is by no means predetermined here. What is necessary is a sustained effort, smart management and coordinated actions on the part of the governments of different levels and other stakeholders to make sure that the sporting facilities do not become white elephants but bring further social (if not financial) value. 
Another point of public criticism has concerned the most expensive non-sporting investment in the Sochi project: a combined motorway and railroad link, comprising tunnels and bridges through the mountains and connecting the coastal and mountain clusters. Olympstroy reported that the project had cost RUB 317.9 billion (some US\$10.3 billion), ${ }^{42}$ or 21 per cent of Sochi's total allocated funds (effectively, this project alone cost more than the wide majority of the Olympic Games beforehand). It was built to serve as the main traffic artery during the Games, allowing a flow of up to 20,000 passengers per hour. ${ }^{43}$ The utilisation of the roads has been low ever since, however, undermining the rationale for its expensive construction and maintenance. ${ }^{44}$

Ahead of the Sochi Games, much investment, especially private, went into the real estate construction sector, and not just into hotels but housing as well. Sales of residential properties have not been as intensive as expected, however, especially in the wake of the economic slowdown though this is, overall, a highly speculative market. ${ }^{45}$ Of particular concern are reports of 'ghost settlements' emerging around housing originally built for residents relocated from expropriated plots. For example, in one settlement, only 17 of the total 79 detached homes are reported to have been occupied since they were built in 2011 , some others being vandalised. ${ }^{46}$

On balance, it appears that the extent to which Sochi will actually become a magnet for tourism, further sporting events, conferences and other commercial and non-commercial activities - and, indeed, a growth pole of national (and international) significance - is not as yet certain but rather remains dependant on the sustained effort to further capitalise on the work already undertaken, including by government itself.

\section{Conclusion}

As already stated, Sochi needs to be seen in the light of the wider political project of Russian modernisation, the logic of which stretches beyond pure financial calculus. Although this approach 
has been conventionally criticised (as being wasteful, ad hoc and exposed to corruption risks), ${ }^{47}$ one result is the re-emergence of spatial policy in Russia, which seeks to rebalance growth away from Moscow and to recalibrate the traditional sectoral approach of the federal government's modus operandi to the spatial approach of territorial development and urban policy. Following the disorganisation (and even degradation) of the national regional policy and spatial planning in Russia after the collapse of the planned economy of state socialism in the 1990s, various mega-events and mega-projects have recently become a 'hook' for the government to regain control over spatial and urban redevelopment policy. Sochi has become one of the most prominent cases in this new spatial policy in Russia. ${ }^{48}$

The urban conditions and infrastructure of Sochi prior to the Games were certainly poor, and the Winter Olympics have radically changed the city's fortune. Focusing on selected locations intensifies the spatial and social inequalities of a country that has already been unevenly developed and socially divided, however. The scale of the mega-projects also makes them less sensitive to public oversight, exposing the democratic deficit and corruption risks. This is a generic problem inherent to all mega-events, but it is more conspicuous in quasi-authoritarian emerging capitalist economies. It is yet a matter of political choices: political elites undertake such projects over and over again in hopes of certain gains, disregarding their opportunity costs. Ultimately, a key factor for politicians is the electorate's support. In this respect, it must be encouraging for the Putin government that, a year after the Winter Olympics, according to a survey by the Russian Public Opinion Research Center, 75 per cent of Russians said they would still support the holding of further sporting mega-events in the country. ${ }^{49}$

\section{Notes}

\footnotetext{
${ }^{1}$ Oleg Golubchikov is Senior Lecturer in Human Geography at Cardiff University's School of Planning and Geography.
} 
${ }^{2}$ Anti-Corruption Foundation, Sochi 2014: Encyclopedia of Spending (Moscow: Anti-Corruption Foundation, 2014), http://sochi.fbk.info/en.

${ }^{3}$ See, for example, The Economist (UK), 'Castles in the sand: the most expensive Olympic games in history offer rich pickings to a select few', 13 July 2013, www.economist.com/news/europe/21581764-mostexpensive-olympic-games-history-offer-rich-pickings-select-few-castles; The Economist (UK), 'Sochi or bust: the conspicuous dazzle of the games masks a country, and a president, in deepening trouble', 1 February 2014, www.economist.com/news/briefing/21595428-conspicuous-dazzle-games-masks-country-andpresident-deepening-trouble-sochi.

4 Bent Flyvbjerg, 'What You Should Know about Megaprojects and Why: An Overview', Project Management Journal, vol. 45 (2014), p. 6.

${ }^{5}$ See Martin Müller, 'After Sochi 2014: Costs and Impacts of Russia's Olympic Games', Eurasian Geography and Economics, vol. 55 (2014).

${ }^{6}$ See, for example, Emil Persson and Bo Petersson, 'Political Mythmaking and the 2014 Winter Olympics in Sochi: Olympism and the Russian Great Power Myth', East European Politics, vol. 30 (2014).

${ }^{7}$ Oleg Golubchikov and Irina Slepukhina, 'Russia: Showcasing a "Re-Emerging" State?', in Jonathan Grix (ed.), Leveraging Legacies from Sports Mega-Events: Concepts and Cases (Basingstoke: Palgrave Macmillan, 2014).

${ }^{8}$ Oleg Golubchikov, 'World-City-Entrepreneurialism: Globalist Imaginaries, Neoliberal Geographies, and the Production of New St Petersburg', Environment and Planning A, vol. 42 (2010).

${ }^{9}$ See, for example, Neil Brenner, New State Spaces: Urban Governance and the Rescaling of Statehood (Oxford: Oxford University Press, 2004).

${ }_{11}^{10}$ See, for example, Anti-Corruption Foundation (2014).

${ }^{11}$ For an overview of Sochi projects and the Olympic legacy from the Games there, see International Olympic Committee, 'Sochi 2014: Facts and Figures', factsheet (Lausanne: IOC, 2015), www.olympic.org/Documents/Games_Sochi_2014/Sochi_2014_Facts_and_Figures.pdf.

${ }^{12}$ The costs reported in US dollars depend on the exchange rates used for the Russian rouble, which have fluctuated much during the execution of the project (and even more so after the Games). It is not entirely correct to convert the costs into dollars at the date of their reporting, as investments are cumulative, so that each period needs to be converted separately. However, this makes it difficult to make conversions in practice. For the purpose of simplification, this article uses the average annual nominal exchange rates of 30.86 roubles per US $\$$ for the five year period of $2009-2013$, when the overwhelming majority of spending was made. The Central Bank of Russia reports daily rates and average nominal exchange rates; see www.cbr.ru/currency_base/dynamics.aspx and http://www.cbr.ru/statistics/?Prtid=svs\&ch=Par_57946.

${ }^{13}$ See the Olympstroy website for its financial reports: www.scos.ru/ru/about/financial/index.php?id_101=3153; www.sc-os.ru/common/upload/otchet_2013/form_14.pdf. ${ }_{14}$ The Accounts Chamber of the Russian Federation, 'Analiz mer po ustraneniyu narusheniy pri podgotovke i provedenii XXII Olimpiyskikh zimnikh igr i XI Paralimpiyskikh zimnikh igr 2014 goda v Sochi', 10 April 2015, http://audit.gov.ru/press_center/news/21280.

${ }^{15}$ Müller (2014) claims that more than half the non-sports-related costs were cost inflation on account of the Olympics that would not have occurred otherwise.

${ }^{16}$ At the average nominal exchange rate of 27.68 in the first half of 2006 (according to the Central Bank of Russia). If rouble inflation is factored in, RUB 313.9 billion in December 2005 translate into RUB 618.5 billion in December 2013, meaning that the final overspend was much less than on dollar-based calculations. Price inflation was already assumed in the FTP, however.

${ }^{17}$ Government of the Russian Federation, 'Decree from 08.06.2006 N357 on the Federal Target Programme "The Development of the City of Sochi as a Mountain Climate Resort (in 2006-2014)"'.

${ }^{18}$ Large overspends are not unique in the worldwide context of mega-projects. As indicated by one of the most prominent commentators on the subject, Bent Flyvbjerg (2014, p. 6), there is the 'iron law of megaprojects': over budget, over time, over and over again. At one extreme, the budget for the 1976 Montreal Summer Olympics was overspent 14 times.

${ }^{19}$ The Anti-Corruption Foundation (2014), on the basis of an analysis of corporate reports and federal budgets, has estimated the following breakdown of RUB 1.5 trillion of the total Sochi costs: direct public budget costs - RUB 855 billion; expenses of state corporations - RUB 343 billion; VEB loans to private companies - RUB 249 billion; equity of private companies - RUB 53 billion.

${ }^{20}$ RBC (Russia), 'Stoimost' Olimpiady v Sochi perevalila za 1.5 trln rub.', 4 February 2013, http://top.rbc.ru/economics/04/02/2013/843458.shtml.

${ }^{21}$ For example, for earlier corruption cases in Olympstroy, see Gazeta.ru, 'Sledovateli zayavili o korruptsii v "Olimpstroye" na $23 \mathrm{mln}$ rubley posle otstavki Bolloeva', 31 January 2011, www.gazeta.ru/news/business/2011/01/31/n_1682318.shtml.

${ }^{22}$ Famously, Jean Franco Kasper, then president of the International Ski Federation (FIS) and a member of the International Olympic Committee, was reported saying that a third of the budget of the Games was 
stolen. He later underplayed the claim as rumours rather than his personal estimate, however. See:

Vedomosti (Russia), 'Chlen MOK: Tret' deneg na Olimpiadu v Schoi rastrachena iz-za "razgula korruptsii"', 10 January 2014, www.vedomosti.ru/business/articles/2014/01/10/chlen-mok-tret-deneg-na-olimpiadu-vsochi-rastracheno-iz-za; RT (Russia), 'Sochi Olympics venues, sports infrastructure most modern in the world: IOC official', 28 January 2014, http://rt.com/news/sochi-modern-venues-ioc-273.

${ }^{23}$ This also exposed the state-owned bank VEB, which provided a loan of US $\$ 1.67$ billion for this particular development; see Forbes, 'Milliarder na Olimpe: kak Potanin stal glavnym chastnym investorom Sochi-2014', 30 January 2014, www.forbes.ru/milliardery/250267-milliarder-na-olimpe-kak-vladimir-potanin-stal-glavnymchastnym-investorom-sochi. It is also noteworthy that the Accounts Chamber of the Russian Federation complained in 2012 about VEB financing knowingly loss-making projects;see, for example, Izvestia (Russia), 'Olimpiyskiye kredity ushli v ofshor', 29 August 2012, http://izvestia.ru/news/533192.

${ }^{24}$ Boris Nemtsov and Leonid Martynyuk, 'Zimnyaya Olimpiada v Subtropikakh' (Moscow, Nemtsov: 2013), www.putin-itogi.ru/zimnyaya-olimpiada-v-subtropikax; Nezavisimaya Gazeta (Russia), 'Korruptsiya ustanovila olimpiyskiy rekord', 7 June 2010, www.ng.ru/economics/2010-06-07/1_corrupciya.html.

${ }_{26}^{25}$ Anti-Corruption Foundation (2014).

${ }^{26}$ Nemtsov and Martynyuk (2013).

${ }^{27}$ On progress with transparency in Russia's state corporations, see Transparency International Russia, 'Monitoring the Transparency and Compliance of State-Owned Enterprise in Russia',

http://transparency.org.ru/en/news/russian-state-corporations-need-to-take-further-anti-corruption-measures.

${ }^{28} \mathrm{See}$, for example, Izvestia (Russia), 'Olimpiyskiye stroyki poluchili pervye ugolovnye dela', 9 August 2012, http://izvestia.ru/news/532535.

${ }^{29}$ RT (Russia), 'Olympic overstate: Sochi embezzlement reaches \$506mn', 6 March 2013, http://rt.com/news/sochi-embezzlement-overstating-costs-901.

${ }_{30} \mathrm{See}$, for example, a response of the Accounts Chamber to a request of Russia's Republican Party

following Nemtsov and Martynyuk's (2013) report: $h t t p: / / s v o b o d a n a r o d a . o r g / n e w s \_p a r t / 4144$.

${ }^{31}$ Vedomosti (Russia), 'Olimpiyskiye geroi', 3 June 2014,

www.vedomosti.ru/newspaper/articles/2014/06/03/olimpijskie-geroi.

${ }^{32}$ For example, Human Rights Watch produced an extensive report on migrant workers: Human Rights Watch, Race to the Bottom: Exploitation of Migrant Workers ahead of Russia's 2014 Winter Olympic Games in Sochi (New York: Human Rights Watch, 2013),

www.hrw.org/sites/default/files/reports/russia0213_ForUpload.pdf. For references to other concerns, see Human Rights Watch (US), 'Russia's Olympian abuses', 8 April 2013, www.hrw.org/video-

photos/interactive/2013/04/08/russias-olympian-abuses.

${ }^{33}$ Vedomosti (Russia), 'Trassa svernula v Sochi', 29 April 2015.

${ }^{34}$ According to travel agencies, during Russia's traditional May holiday break, Sochi in 2015 replaced Paris as the most popular destination among Russians, seeing an 80 per cent increase in ticket sales for this period from a year earlier: RBC (Russia), 'Kuda edut na mayskiye prazdniki: Sochi, Simferopol i Tel-Aviv', 17 April 2015, http://top.rbc.ru/business/17/04/2015/55310fc79a7947d461cb9607.

${ }^{35}$ Gazeta.ru, '“Vse eto delalos' ne dlya sochintsev"', 5 February 2015, www.gazeta.ru/social/2015/02/04/6399989.shtml.

${ }^{36}$ Ibid.

${ }^{37}$ See International Olympic Committee (2015).

${ }^{38}$ Sochi has 55,000 hotel rooms, exceeding the 41,300 in Moscow: Vedomosti (Russia), 'Sostyazaniye za 1.5 trln', 27 December 2013.

${ }^{39}$ The Washington Post (US), 'Russian economic crisis helps save Putin's post-Olympic dream at Sochi', 18 January 2015, www.washingtonpost.com/world/europe/russian-economic-crisis-helps-save-putins-postolympic-dream-at-sochi/2015/01/17/d8c7bbd8-92b1-11e4-a66f-

Oca5037a597d_story.html?Post+generic=\%3Ftid\%3Dsm_twitter_washingtonpost.

${ }^{40}$ For a review of the planned and current use of sporting facilities in Sochi, see Gazeta.ru, 'Olimpiada v Sochi: God Spustya', www.gazeta.ru/sport/sochi2015.

${ }^{41}$ For further discussions on this, see, for example, Müller (2014).

42 Olympstroy (Russia), 'Otchet ob osuschestvlenii stroitel'stva olimpiyskikh obyektov i vypolnenii inykh meropriyatiy, svyezannykh so stroitelstvom olimpiyskikh obyektov za 2013 god', p. 16, www.sc-

os.ru/common/upload/otchet_2013/form_14.pdf.

${ }^{43}$ Rossiyskaya Gazeta (Russia), 'Igry vysshey proby', 12 April 2013.

${ }^{44}$ Some estimates suggest that the costs that the government has to incur in order to subsidise, operate and maintain post-Olympic venues and tourist and transport infrastructures in Sochi may remain well above US\$1 billion per year; see Müller (2014).

${ }^{45}$ Kommersant (Russia), 'Igry, $v$ kotorye igrayut v Sochi: kogda okupitsa olimpiyskoye nasledstvo', 8 September 2014, www.kommersant.ru/doc/2554133. 
${ }^{46}$ Kavkazskiy Uzel (Russia), 'V Sochi predstaviteli obschestvennosti napravili prezidentu akt obsledovaniya pustuyuschego poselka dlya olimpiyskikh pereselentsev', 3 April 2015, www.kavkaz-uzel.ru/articles/259950.

${ }^{47}$ See, for example, Martin Müller, 'Higher, Larger, Costlier: Sochi and the 2014 Winter Olympics', Russian Analytical Digest, vol. 143 (2014); Robert Orttung and Sufian Zhemukhov, 'The 2014 Sochi Olympic MegaProject and Russia's Political Economy', East European Politics, vol. 30 (2014).

${ }^{48}$ See Golubchikov (2010); Nadir Kinossian, 'Stuck in transition: Russian regional planning policy between spatial polarization and equalization', Eurasian Geography and Economics, vol. 54 (2013).

${ }^{49}$ Russian Public Opinion Research Center, 'Olimpiada v Sochi: god spustya', 5 February 2015, http://wciom.ru/index.php?id=236\&uid=115138. 